\title{
The Security Environment of the V4 Countries
}

\author{
JAROSLAV UŠIAK
}

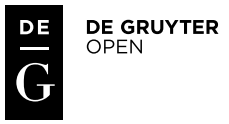

Politics in Central Europe (ISSN: 1801-3422)

Vol. 14, No. 2

DOI: $10.2478 /$ pce-2018-0007

\begin{abstract}
State security policy is not created in a vacuum. In general, policy-making is affected by external and internal variables and influences on the security environment as well as by responses to all these factors. Political decision-making is another significant intervening variable. The aim of this study is to define the security environment of the Visegrad countries in both its narrow and broader senses. To this end, I consider common factors that have affected - and continue to influence - all four countries in order to reveal and evaluate the policy development processes in these states up to the present day. My methodology relies on case studies that trace the security policies of each of the Visegrad countries since the end of the bipolar standoff. The comparison in my conclusion highlights significant challenges now affecting the security policies of all these countries including defence budgets, the crisis in Ukraine, the position of EU member states and growing nationalism and extremism.
\end{abstract}

Keywords: Central Europe, security environment evolution, security threats, security challenges, the V4

Security - as defined in a state's security policy - is one of the most important elements of its foreign and defence policies. These elements determine the direction of foreign policy and, thus, they are often introduced together in state (and organisational) documents. For this reason, it is important to tie any security policy to a concrete foreign policy doctrine when assessing domestic developments. The aim of this study is to define the security environment of the V4 countries from both narrow and broader perspectives. In the process, I identify the main factors that have affected individual V4 countries and their current influences in order to outline and critically assess developments in these states. My methodology relies on case studies that track the security policies of 
the V4 countries since the collapse of the bipolar world division. I draw here on the work of other authors who have been undertaking long-term work on the security policies of particular V4 countries. The central pillar of this research is an analysis of state documents, and this is supplemented by studies and other accessible publications by authors from the states in question (see, for instance, Nowakowski - Protasowicki (2008); Czulda - Madej (2015); Karaffa - Balabán - Rašek (2008); Kořan et al. (2014); Kmec - Korba - Ondrejcsák (2005); Goda et al. (2017); Almási - Kádár (2005)' Balogh (2013). These authors highlight and evaluate the development processes in their own countries.

The main geopolitical changes that have influenced current relations among these states took place mostly in the last decade of the 20th century. Before this, the V4 countries were an integral part of the Soviet bloc, which determined their regimes, their political orientation and their economic dependence. After the disintegration of the Soviet bloc, these Central European countries sought out a new direction. While all of them had become independent, their natural and human resources were limited and they remained dependent on other states when it came to economic and, in particular, energy matters. The main factor affecting Central Europe's development was its turn to the European Union, a move made with the expectation of achieving economic stability and prosperity. On the other hand, these states continued to rely on the Russian Federation for mineral resources. As far as security was concerned, after the regime change, the Central European states focused on their integration into international security structures. They became members of the United Nations in 1993 and the Organization for Security and Cooperation in Europe (OSCE, previously known as CSCE) in 1995. Their development was shaped by the Partnership for Peace programme and later by their integration into the North Atlantic Treaty Organization (NATO). In terms of economic integration, European Union membership remained the main objective. Today the V4 countries are all fully-fledged members of both NATO and the EU. These two organisations have a significant effect on their stances on security and other issues.

\section{The Central European Security Environment at a Crossroads}

The rapid transformation of the $\mathrm{V} 4$ countries into members of CSCE/OSCE, the EU and NATO meant they never reflected adequately on the Cold War period and its impact on their security policies. In the years after the Second World War, all these states were exposed to the Warsaw Pact and fell under the influence of the Soviet Union, which also held considerable sway over their security policies. Moreover, the years 1956, 1968 and 1981 were important milestones for Hungary, Czechoslovakia and Poland respectively, marking the arrival of Warsaw Pact troops or the start of a political intervention designed to enhance stability and protect socialism (Pástor 2004: 23). The bipolar system ultimately 
came undone under the weight of ideological and security conflicts. The fundamental changes that brought about this collapse occurred first within internal political systems and only later transformed international politics. Though the confrontation between the two blocs was over, a new polarisation with its own security threats had begun.

Mikhail Gorbachev's speech on the floor of the Council of Europe in July 1989 may be considered a breakthrough event. This address prefigured major developments including the USSR's deviation from Brezhnev's doctrine, its decision not to maintain Soviet satellites in its sphere of influence, the dissolution of the Warsaw Pact (which eventually occurred in 1991) and ultimately the collapse of the USSR and reactions to the end of the bipolar system. The East European states were faced with new challenges that demanded an appropriate response. As such, these states and their representatives had to decide on the most suitable of seven alternative approaches: a) neutrality (with or without institutional security); b) establishment of their own independent regional security organisation; c) engagement in an existing regional security organisation and its subsequent transformation; d) revival of an Eastern (European) security organisation; e) integration into Western security structures; f) creation of some kind of pan-European security architecture or g) reliance on national defence exclusively (Nagy - Kovács 2006; Cottey 1995).

As they attempted to decide on a position, these states were concerned about the USSR's potential recovery of its strength and power and they struggled to overcome a dependency established over decades. Analysing each of these alternatives should reveal the one most conducive to these states' interests, and I review the options in greater detail in the sections on individual countries. At this point, however, it is worth summarising some key concerns around the seven approaches. On the option of neutrality, it was clear that this "soft" approach (i.e. neutrality without institutional support) offered no security guarantees but these states lacked the backing for the "hard" version that might have come from the UN Security Council, for example. At the same time, they opposed forming their own regional security organisation since they had different (and at times even opposed) interests. Turning to the option of integration into an existing regional security organisation that would then be transformed, they considered CSCE/OSCE but noted that it had never exercised military force and could not guarantee their defence. Similarly, the revival of an Eastern security organisation was highly unappealing given their historical experience. Integration into Western structures was more attractive though it too seemed unrealistic since NATO had not adopted an enlargement policy. Still, this option promised to connect them directly with a guarantor of regional defence and security. The creation of some kind of pan-European security architecture also appealed to European states (and especially those of Central and Eastern Europe), but in practical terms looked onerous if not 
impossible. The last alternative - development of national defence - was considered prohibitively expensive given the states' obsolete defence technology and the need for large investments in transformation.

Ultimately, the Central European states decided on options b), e) and to some extent g). The plan sketched out in option b) was implemented through the creation of the V3 (and subsequently V4) alliance, which gave these states the chance to cooperate in preparation for their integration into Euro-Atlantic structures. Option e) was seen as optimal given the benefits of NATO membership and the potential for a new security and defence structure in the context of European Union membership.

Today the V4's security policy is influenced significantly by these states' NATO and EU memberships, which provide a framework for their decisions, involvement and positions. While the EU has focused primarily on economic integration over the last few years, it has also established some instruments that may affect security and defence policy. I refer particularly here to the Common Foreign and Security Policy (CFSP) and the European Security and Defence Policy/Common Security and Defence Policy (ESDP/CSDP). At the same time, current circumstances suggest the need for NATO's continued engagement on the European continent since its position considerably affects the security policies of its member states.

The following sections provide an analysis of the security policies of the individual V4 countries. For this purpose, I have defined specific historical periods according to the milestones in a particular country or the strategic decisions that it had to make. I do not enumerate all events occurring in this context but focus instead on the ones which were most important, substantive and decisive and, thus, helped to shape and develop the state and its security policy.

\section{Basic development of foreign and security policies of the V4 countries}

Understanding the development of the V4 states' security policies is essential in the context of their cooperation. Clearly, however, these security policies are not created in a vacuum; they are influenced by not only the evolution of the security environment but also internal political conditions in individual states. In this section, I outline the main phases of development in all four states that set the course for their future orientation.

\section{The Czech Republic}

The Czech Republic's security context may be seen as historically unchanging in terms of external borders. As far as the domestic security environment is 
concerned, however, there have been frequent changes in the image of the external enemy and the nature of both regional and global threats and risks.

For our purposes, the first critical period ran from 1989 to 1993 and also involved the Slovak Republic. These years were marked by the collapse of the bipolar system, which brought new dimensions to international relations and launched new processes that continue to this day. The Czech Republic became part of the Czech and Slovak Federal Republic (CSFR), a shift that profoundly changed not only the country's political configuration but also the nature of its security and its outlook. Shortly after its creation, the CSFR had to deal with multiple problems including the withdrawal of Warsaw Pact troops from its territory, which was finally achieved in 1991 (Khol 2004). The CSFR remained a member of the Warsaw Pact until mid-1991. That year also saw the dissolution of the USSR, resulting in new security arrangements across Europe that each state had to contend with. The CSFR immediately sought to enter the European Communities (EC). At the same time, it applied for NATO membership, having identified NATO as a critical security guarantor (Khol 2004). More changes ensued in 1992 with signs emerging of separatist programmes in the Czech and Slovak state. This situation led to the establishment of two separate republics in 1993 - the Czech Republic and the Slovak Republic. Among the difficult tasks confronting both these states were their transformation into market economies, the establishment of the rule of law and the shaping of their national security environment and security policies.

The second key period (1993-1999) was dominated by the Czech Republic's efforts to establish a national defence and security identity even though its security policy had not yet taken shape. The dissolution of the CSFR brought an end to the State Defence Council, the central state administrative authority that had been responsible for implementing security policy. The emphasis began to shift to the defence side of security policy to be implemented by the Ministry of Defence. As in the other V4 states, however, politicians did not see security and defence policies as pressing concerns - their primary objectives remained creating democratic institutions and rules and overseeing the transition to a market economy and the relaxation of the planned economy. It was only in 1996 that security emerged as a separate item on the Czech government's agenda, a shift linked to the decision to join NATO (Mazalová 2006). At the Madrid NATO summit in 1997, the Czech Republic was invited to start accession negotiations. These negotiations ended while Prime Minister Vaclav Klaus was still in power, ${ }^{1}$ that is, shortly before the appointment of the caretaker Tošovský government (which pursued accession without any significant

1 Despite the Czech Republic's efforts at the start of the negotiations, it had not met the accession criteria in all six areas identified by Borkovec (2008:24): "political, legislative, defence criteria (defence planning, interoperability, infrastructure, and defence industry), resources (economic and human), information security and public support." 
changes) and the early elections that put Milos Zeman into office (Karaffa et al. 2008: 7). Zeman's government also stayed the established course on integration despite early indications from some members of the ruling party that the Czech Republic might choose a different course based on the Danish and Norwegian examples. In fact, Zeman's government finalised the necessary steps and the Czech Republic joined NATO in March 1999.

The third critical period (1999-2007) was marked by problems around the transformation and interoperability of the Czech army and its transition to a fully professional force in 2005. Other issues in this period concerned the meaning of NATO membership itself; like the citizens of other V4 countries, Czechs had distorted ideas about NATO's operations and the obligations of its member states. This problem had already been apparent in the spring of 1999 when the Kosovo crisis led to the establishment of new NATO operations and the Czech Republic faced a decision about whether to support air strikes. Czech politicians divided into two clear camps, with supporters of the action (a group including President Vaclav Havel and politicians from various parties (KDU-ČSL, ODA) on one side and its opponents (then prime minister Zeman and then assembly chairman Klaus) on the other. The Czech public remained ambivalent about the proposed proactive steps and it refused to support the operation. Politicians favouring the intervention faced a formidable task: wanting to maintain the country's image as a responsible and credible partner, they had to justify unpopular steps to the people. This period was also complicated by changes in EU and NATO operations as both organisations significantly altered the scope and substance of their activities after Czech accession (Khol 2004: 35). Other milestones included the 11 September 2001 terrorist attacks, the 2002 NATO summit in Prague (an important opportunity for the Czechs to prove their reliability and readiness for future action) and the 2003 Iraqi crisis in which the country supported US policy. By the latter action, the Czech Republic took a stand against the European coalition that opposed the invasion and recognised the United States as a strategic partner.

The era that followed (2007-2013) was one of maintaining of the established course with the aim of achieving deeper integration and cooperation on security issues. The Euro-Atlantic integration process concluded with the accession of all of the V4 countries to NATO and the EU. The Czech Republic, thus, became part of a neighbourhood of states with shared values and institutional anchoring; this was a significant expansion of security whose implications went beyond the country's external borders. The need to support NATO and the EU through contributions of the Czech Republic's own capacities was - and remains - a major issue for national security policymakers. These years also saw the convergence of the two main streams of Czech security policy: its Atlantic and European components. The Czechs supported and participated in EU military operations (e.g. EU ALTHEA in Bosnia and Herzegovina) and civilian missions (e.g. EUFOR 
in Chad). They also contributed to the EU defence architecture by establishing the EU Battlegroup together with the other V4 countries (described in this article as the V4 EU Battlegroup or V4 EU BG) (Kořan et al. 2014). These steps were backed up by various national strategic documents, ${ }^{2}$ which shed further light on the Czech position on the CFSP-related obligations arising from EU membership and, in particular, the defence dimension of ESDP/CSDP.

The last key period begins in 2013 and is ongoing. Czech security policy in this era has been characterised by a persistent ambivalence about NATO and the EU in the area of ESDP/CSDP. This dual-track approach has, however, been typical for most Central European states. A second problem concerns the allocation of funds for the purpose of upgrading the Czech army in order to fulfil the country's obligations under Article 5 of the Washington Treaty and its defence commitments vis-à-vis the EU. A third issue is the need for clarification of the Czech position on the conflict in Ukraine and, thus, also indirectly on Russia and East-West relations. This situation has been affected by the crisis in Ukraine that emerged in November 2013 and the related migration crisis. Divisions in the Czech Republic over the nature and impact of the conflict (Buchtík - Leontiyeva 2014: 4-5) reflect the different positions put forward by President Zeman and the previous Sobotka government (it is also worth mentioning the stance of Foreign Affairs Ministry political secretary Petr Drulák, who has called for Czech neutrality). For security purposes, this clarification of the Czech position is important. In this context, domestic political issues will likely determine the direction taken on security and foreign policy.

According to Kořan (2012b), when it comes to the development of the country's foreign and security policies, Czech politicians have fallen into two camps: a dissident school (cf. Waisová 2010; Waisová - Piknerová 2012) and a school grounded in liberal economics. While the former has favoured a pro-Atlantic position because of the emphasis on supporting human rights and combating abuse, the latter has stressed the economic benefits of this positon. In other words, although the ideological motives of these camps have differed, their outcome has been the same (Kořan 2012b). The evolution of Czech security policy can also be understood in terms of two main plots. The first of these began with a clear focus on NATO membership immediately after the establishment of the independent state; it has since run into difficulties as the Czech Republic struggles to find its own place in the organisation. The second plot traces the complications around the country's efforts to find a consensus on the most appropriate European security architecture and, thus, a position on the ESDP/ CSDP and CFSP frameworks.

2 These documents included the 2008 Czech Military Strategy, the May 2011 Czech Defence White Paper, the September 2011 Czech Security Strategy and the 2012 Czech Defence Strategy. 


\section{The Slovak Republic}

The account below highlights the four key eras of Slovak security policy development. The first of these (1989-1993) was one of shared experience with the Czech Republic, and thus, is covered in the section above.

The second period (1993-1998) began with the division of Czechoslovakia and was characterised by indecisiveness and unfavourable domestic developments. These first years of independence were a time of shaping Slovak statehood. Given the geopolitical circumstances, the country's representatives sought to integrate into existing international organisations, an approach that promised to deliver a reasonable profit when set against the required costs. Vladimir Mečiar's government announced Slovakia's wish to join NATO and the EU. In this context, the year 1997 marked a turning point: just as the national debate about NATO culminated, Slovakia took steps to join the Commonwealth of Independent States (CIS), a move that some politicians saw as incompatible with EU and NATO integration (Exchange of experience in Partnership for Peace Program Implementation 1998). Slovakia would eventually become a sort of a bridge between the West and the East, and even at this point, some voices called for neutrality. At the same time, foreign partners took a negative view of the failed February 1997 referendum on Slovakia's potential NATO membership. Slovak politicians' comments also exposed internal tensions in the country around security (Ušiak 2012). While at the international level, some of these individuals promoted Slovak accession to NATO and the EU, on the domestic scene, others revealed a schism about the country's future security policy. Moreover, the development of the Slovak army lagged behind the armies of other states, and this ultimately also contributed to the rejection of Slovakia's integration by external parties.

The third era (1998-2006) saw the suspension of plans for NATO integration as Slovakia faced the need to restart this process. The domestic situation changed after the 1998 elections when Mikuláš Dzurinda's government took office. The effects of this shift went beyond internal political developments, with clear trans-Atlantic goals being set in the area of security. This helped revive the negotiations on Slovakia's accession to both the EU and NATO. The new prime minister faced major challenges including changing the attitudes of partners with a significant influence over Slovakia's integration into Western structures and presenting a new position in the country's strategic security documents. Other key tasks included overseeing the required transformation of the Slovak army and creating space for public debate about Slovakia's approach to trans-Atlantic structures. These issues were addressed in much of the security policy during Dzurinda's first term in office. In 1999, Slovakia participated for the first time in an operation launched under the auspices of NATO. This was the SFOR mission. All these steps were appreciated by foreign partners, including the 
most important player - the United States. The years 2000 and 2001 brought more reforms and more positive statements from foreign partners (Kmec et al. 2005). As a result, at the NATO summit in Prague in 2002, Slovakia was one of the seven countries invited to join NATO in a second round of enlargement. (The other invited states were Bulgaria, Estonia, Latvia, Lithuania, Romania and Slovenia.) With the outbreak of the Iraqi crisis in early 2003, Slovakia had to defer to the UN Security Council's decision and it eventually deployed 75 Slovak soldiers. Although this mission's official mandate was only for the Kuwait area, it had the option to enter Iraq in the event of the latter's use (or reasonably suspected use) of weapons of mass destruction.

The final major period begins in 2006 and has been focused on Slovakia's membership of NATO and the EU. In early 2006, the Slovak army was professionalised under Act No. 346/2005 on the State Service of Professional Soldiers in the Slovak Army. The main goals of the statute were the gradual elimination of compulsory military service and the full professionalisation of the army by the beginning of 2006. A more significant change came after the 2006 elections when Robert Fico took charge of the government. Fico held power for more than a decade, with only a brief interruption when Iveta Radičová became prime minister. Radičová made changes to the country's security and defence policy in response to the emerging financial crisis and concerns about the level of national defence funding. Under her watch, a process of strategic defence evaluation was also begun. Its findings included the need to bring the state's financial framework into line with Slovakia's political ambitions and essential military reforms. During his next two terms in office, Fico developed a security policy based around the crisis in Ukraine, the migration crisis and Slovakia's position on the EU "core." It remains an open question how all this will affect the country's future security policy. Political protests in the spring of 2018 brought an end to Fico's reign, with Peter Pellegrini replacing him as prime minister. To date, however, this change has not significantly influenced Slovak foreign and security policies. Instead, the country has maintained its ambivalence about many important security questions.

\section{The Republic of Poland}

Historically Poland's security policy was shaped by a distrust of European allies after the country's invasion in 1939 and betrayal in Yalta in 1945. These events caused Polish leaders to focus on finding trustworthy partners and ensuring the country's own reliability. The more recent development of Polish security policy can be divided into four main eras.

The first of these periods (1990-1999) corresponded with with the years of integration into the North Atlantic Alliance. During this time, domestic political developments were largely influenced by Lech Wałęsa, the president elected in 
1990. Wałęsa managed to restore stabilility after the first free elections in 1991 when a struggle erupted among various parties and politicians in the Sejm, the lower house of Polish parliament. After the 1993 elections, the political leaders' attention turned to Western organisations, particularly the European Communities and NATO, along with the development of relations with Germany (Nowakowski - Protasowicki 2008). At the same time, Poland continued to intensify its relations and ties with the United States.

The second period (1999-2004) began with Poland's integration into NATO and was dominated by preparations for accession to the European Union. These years confirmed the country's pro-Western orientation. The integration process and negotiations were completed in 2004 when Poland joined the EU. In addition, Poland made efforts to prove its strategic significance as a Central European state to NATO. Polish leaders expressed strong support for the United States especially after the 9/11 terrorist attack, endorsing both operation Enduring Freedom in Afghanistan in 2002 and the American invasion of Iraq in 2003. In this way, Poland became one of the main proponents of US policy in Europe (Longhurst - Zaborowski 2007). Many authors have identified this alliance with the US as the third pillar of Polish national security alongside the country's partnerships with NATO and the EU. On this view, none of these pillars is most important, and they all have equal significance. On the other hand, it is true that support for the development of a European defence structure lagged significantly behind during these years.

The third key period (2004-2013) was organised around Poland's responses to major events, including its EU accession, the conflicts in Afghanistan and Iraq and other international crises. At the same time, Poland was required to respond to activities under the Common Security and Defence Policy. In this regard, Poland supported the development of the EU's own capacities while simultaneously maintaining its alliance with the US, which remained its main partner. Since the establishment of the ESDP in around 2000 (i.e. during the integration period), Poland had consistently refused to develop the policy, which it believed was being advanced at the expense of the European security and defence identity (ESDI) strategy (Pomorska 2011). ${ }^{3}$ In 2009, the Polish army completed its transformation as part of the required adaptations for NATO and EU membership. Compulsory military service was eliminated and a professional army introduced. A turning point in the country's stance on ESDP came with the resolution of major differences about the nature of its operations. Also significant was the weakening of the US-Polish partnership after the failure to

3 The ESDI policy promoted a stronger alignment with NATO than had been foreseen under the original ESDP proposal. The goal was to ensure the European Union's security and defence. This discrepancy was eventually resolved in the Strategic Partnership Agreement on Crisis Management (known as Berlin Plus) concluded between the EU and NATO. That agreement established a mechanism enabling the EU to access NATO logistical and planning resources including intelligence. 
establish an anti-missile defence system in Central Europe (a situation that was also due to Russian pressure). Moreover, there were claims that any interest promoted within NATO would always remain subject to the decisions of major actors. As such, Poland began to recognise the EU's defence capabilities as a viable alternative for projecting its own power.

The last important period begins in 2013 and has focused particularly on the risk of the situation in Ukraine escalating into a large-scale armed conflict which could potentially affect Poland. At the same time, Poland has sought out the position of leader of the V4 group. Overall, this period has, thus, been marked by three key themes: Polish fears of a major military conflict in Ukraine; the consolidation of Poland's relations with the US as a potential protector (defender) (Machnikowski 2015) and the country's efforts to establish itself as the leader of Central Europe and ultimately also the EU. This post-2013 era has seen a growing awareness in Poland of the country's strength and dominance at least in the Central European region and its impact on decision-making in the EU. As we have seen, towards the end of the previous period, the role of the US was weakened while the position of the EU was strengthened. Subsequent elections resulted, however, in a new government under the leadership of Beata Szydło and the latter was replaced in December 2017 by Mateusz Morawiecki, a strong nationalist. Combined with the resurgence of fears of Russian expansionism in the context of the Ukrainian crisis, this nationalism has seen a renewed emphasis on the importance of the US (NATO) for Poland's defence. ${ }^{4}$

\section{Hungary 5}

Back in May/June 1989, Hungary signalled a new course for its foreign policy when it opened up its borders with Austria so that thousands of East Germans could access the West. Hungary was also one of the initiators of the plan to dissolve the Warsaw Pact (Asmus 2002: 219). The evolution of its security policy can be divided into three discrete periods.

The first of these eras (1990-1999) was dominated by the NATO integration process and Hungary's own efforts to work out a strategic position. This period saw a number of essential reforms to the organisation of state defence. Hungary was the first of the Central European states to unequivocally confirm its pro-West orientation not only in declarations but also in changes to domes-

4 There are several practical examples of this shift. These include Poland's support for a deployment of NATO forces (and especially US troops) to protect the Eastern border, the establishment of a NATO Counter Intelligence Center of Excellence (CI COE) in Krakow and the operation of the Multinational Corps Northeast (MNC-NE) in Szczecin and NATO units in Bydgoszcz. (We could point to many more examples of the NATO-US military presence in Poland in 2018). All this points to the greater importance of NATO/the US for Poland than for the other V4 countries.

5 This text refers to "Hungary," which is the official state name under the currently valid Constitution of April 2011. This replaces the former name "Hungarian Republic." 
tic policy. The first free elections were held in March/April 1990 and the first post-Communist government, which held office from 1990 to 1994, declared NATO integration to be a priority. After the collapse of the USSR, the three Central European states agreed to take a common stance on security, and in 1992, their leaders Václav Havel, Lech Walesa and József Antall met in Prague. Hungary was assured that the ethnic Hungarian minority issue (see below) and its proposed solution would not obstruct the first phase of NATO integration (Almási - Kádár 2005: 262).

The following period (1999-2010) was one of EU accession negotiations and ultimately EU integration. Hungary sought to achieve a strategic balance between the EU and NATO in its internal and external security; at the same time, it applied strategic thinking to the collective defence. While some Central European states had managed to become NATO members less than eight years after the fall of the USSR and the dissolution of the Warsaw Pact, there remained the problem of instability in the Balkans. Hungary was one the main proponents of further NATO enlargement, having found itself in the position of a NATO island in Central and Eastern Europe after 2004 (Nagy - Kovács 2006). As the question of relations among the EU, NATO and the US came to the fore, Hungary tried to find an appropriate position within this triad. In this context, it accepted the strategic benefits of its geopolitical position to both the EU and NATO while noting the advantages that the country gained from its membership and location when it came to external threats that might affect domestic security. Around this time, there were other developments: Hungary became aware of several options for implementing an effective policy on the ethnic Hungarian minority residing within other states. Moreover, the emerging concept of ESDP reinforced the state's interest in an effective EU defence policy that might also draw on NATO's capabilities. Accompanying EU accession, the year 2004 brought several changes to Hungarian security and defence policy including the end of compulsory military service and introduction of a professional army (or troops on contract). These adaptations resulted from Hungary's obligation to ensure the interoperability of its army and its suitability for remote regional operations, special missions and deployment in joint operations and missions within both the EU and NATO. However, like other V4 countries, Hungary also saw a decline in defence spending (Nagy - Kovács 2006). ${ }^{6}$ This trend continues within the V4 to the present day, with Poland being the only exception.

The final key period begins in 2010 and has been a time of strategic decision-making for Hungary between the EU (ESDP/CSDP) and NATO. At the same time, Hungary has established a new path with implications that go beyond the reform of foreign and security policy and the army; it is seeking a new position in East-West relations. Recent years have been dominated by the new approach

6 In 2004/2005, this spending dropped to 1.5/1.4\% of GDP. In contrast, it stood at 1.8\% of GDP in 2001 . 
to foreign policy and security of Viktor Orbán. This approach has four main priorities: expanding Hungary's foreign policy to address more of the world; a greater focus on the Eastern Partnership; adoption of new strategic documents (Balogh 2013: 1) and attempts to secure a new position on the East-West axis. These plans have also found expression in the state's security policy. Statements made by Orbán during the 2014 Ukraine crisis suggested a change in foreign policy, especially concerning East-West relations. ${ }^{7}$ Hungarian political representatives began to promote a redefined concept of Euro-Asianism that clearly named the Russian Federation as a partner especially in the area of trade and energy security (Naxera 2017). The latest steps by Hungarian representatives have triggered a disagreement between Budapest and Brussels and suggest a new stance to Moscow conflicting with the position of most EU members (Haines 2014; Johnson 2014). ${ }^{8}$ In this regard, Hungary has taken a completely different position on the crisis in Ukraine and sanctioning of Russia. Moreover, it has departed significantly from the EU given deepening trade links between Hungary and Russia, the questionable support of factions of the Hungarian government for some Russian actions and Hungary's attacks on foreign NGOs. These actions by Hungary differ from those of its partners in Central Europe (especially Poland) and indicate that Hungary is partly influenced by Russia. The Hungarian public has tended to be ambivalent about the country's position in East-West affairs. In this context, Orbán's pro-Russia policy may be understood as a kind of "pendulum diplomacy" based on cold calculation of the economic and perhaps also social benefits of connnections with Russia. As a result, relations with the EU and NATO (USA) have come under strain and trust has declined.

\section{Common security challenges for the V4 countries}

The security policy of the V4 countries developed in a space that had once been a territorial barrier between empires and later served the same purpose between ideological blocs. By the end of the 20th century, this area had changed significantly and new boundaries had arisen as NATO and the EU expanded into the former Eastern bloc states. A pro-West position predominated in these countries for reasons that were first and foremost economic but also ideological, cultural and social. Combined with a programme of gradual development, this pro-West stance stimulated changes in the security environment (Dančák et al. 2011).

7 This shift had already been signalled by Orbán in the inauguration speech after his re-election in May 2014. That speech had emphasised the need to ensure the recognition of dual citizenship as well as collective rights and autonomy for the Hungarian minority in Trans-Carpathian Ukraine. The area is home to about 150,000 ethnic Hungarians (Orbánov minister zahládza 2014)

8 It should nevertheless be acknowledged that Hungary has so far abided by the sanctions imposed by the EU against Russia. 
Arguably, the contemporary security environment in the V4 countries remains very similar. At present, all these states base their foreign and security policy on NATO's strategic plans. They view NATO as the main guarantor of their security and operate in a context of security-related cooperation between NATO and the EU. At the same time, deeper anti-European tendencies have endured especially in Poland and Hungary. And despite their assurances to the contrary, even Slovakia and the Czech Republic do not always contribute to stabilising the V4 region or its pro-European orientation.

Current V4 security policy rests on cooperation with NATO and the EU as well as on the pro-Euro-Atlantic positions that states maintain regardless of the differing postures of politicians from individual countries. A comparison of security threats across the states also reveals significant similarities. Moreover, there are strong correlations with the updated European security strategy and the strategic concept adopted by NATO in 2010. Still, some minor discrepancies may be observed within both the regional and domestic security environments. Based on the above analysis of security policy development, we may also note a number of key security challenges that will determine the course of the security and foreign policy of the V4 countries and influence their cooperation. These challenges include decreasing defence spending, the crisis in Ukraine, attitudes to the EU (in response to the migration crisis, the building of the EU core and other issues) and finally, the growing influence of nationalism and extremism in all the states in question.

Concerns about shrinking defence budgets are not unique to the states of Central and South-East Europe. Nevertheless, given the global financial crisis (which cannot, however, be seen as the sole triggering event) and the current context of relative stability and no direct military conflict, the V4 states besides Poland have come under pressure to reduce their defence spending, and thus, shirk their obligations as NATO members to allocate 2\% of GDP to defence. These states have tended to behave like freeloaders, relying excessively on others to foot their "bill” (Ušiak - Ivančík 2014) and, thus, becoming "consumers" of security. The second major challenge relates to the ongoing crisis in Ukraine, which has led to a turning point in the cooperation among the Central European states (Hendrych et al. 2017). At present, there continues to be no consensus among these countries about the origins and nature of the conflict, and, thus, the role of the Russian Federation. As such, the attitudes of individual state representatives are often ambiguous. Thirdly, as regards EU policies and instruments, there appear to be several areas of friction including the migration crisis and the role of the EU core. These two problems have been driving the move for greater EU integration in the areas of security and defence. The potential disengagement of one or several V4 countries might endanger cooperation within the V4. The final challenge, and one that goes beyond the V4 countries, concerns the growing popularity of extremism (Bienczyk - Missala et al. 2017) and na- 
tionalist programmes and their transition into political life. These tendencies could put pressure on any kind of transnational cooperation, including the V4. On the other hand, they may reinforce the V4 cooperation as an alternative to higher-level integration. In the next section, I consider some of the opportunities for further cooperation that these challenges have produced.

The analysis and comparison in this study have made clear that the security and foreign policies of the V4 countries have been based on - and continue to reflect - their dependency on great empires or powers. These powers clearly have their own strategic interests. Putting aside the shared values and ideas of the V4, much of their current cooperation is the result of their geographical proximity and active participation in two international organisations - NATO and the EU.

\section{References}

Almási, F. - Kádár, P. (2005): The role of Hungary in NATO, as a political and military alliance, with special regard to the relation of the National Security Strategy to NATO membership. Academic and Applied Research in Military Science 4 (2): 259-274.

Asmus, R. D. (2002): Dvere do NATO. Bratislava: Kaligram,

Balogh, I. (2013): A 2012-es magyar nemzeti katonai stratégia értékelése. MKI-TANULMÁNYOK: A Magyar Külügyi Intézet időszaki kiadványa. Budapest: Magyar Külügyi Intézet.

Bienczyk-Missala, A. - Goda, S. - Hörömpöli, L. - Valuch, J. (2017): Capabilities of the Visegrad Group in preventing extremism. Budapest: Budapest Centre for Mass Atrocities Prevention.

Borkovec, Z. (2008): Deset let od vstupu do NATO. Vojenské rozhledy 18 (4): 23-28.

Buchtík, M. - Leontiyeva, Y. (2014): Postoj české veřejnosti k dění na Ukrajině - ř́jen a listopad 2014. Praha: Centrum pro výzkum veřejného mínění, Sociologický ústav Akademie věd ČR, available at: http://cvvm.soc.cas.cz/media/com_form2content/documents/c1/a7296/f3/ pm141128.pdf.

Cottey, A. (1995): East-Central Europe after the Cold War. London: Macmillan Press.

Czulda, R. - Madej, M. eds. (2015): Newcomers No More? Contemporary NATO and the Future of the Enlargement from the Perspective of "Post-Cold War" Members. Warsaw: International Relations Research Institute.

Dančák, B. - Gniazdowski, M. - Hamberger, J. - Hudek, A. (2011): Two Decades of Visegrad Cooperation. Bratislava: International Visegrad Fund.

Exchange of experience in Partnership for Peace Program implementation. (1998): Bratislava: Military Press and Information Agency.

Haines, J. R. (2014): Hungary: Going in the Wrong Direction? Foreign Policy Research Institute. available at: http://www.fpri.org/articles/2014/09/hungary-going-wrong-direction 
Hendrych, L. - Šimkovič, J. - Kokoszczynski, K. - Zgutová, E. (2017): Visegrádskou skupinu nejvíce rozděluje Putin a Ukrajina. In Euractive.cz, available at: http://euractiv.cz/clanky/visegradska-ctyrka-v-eu/visegradskou-skupinu-nejvice-rozdeluje-putin-a-ukrajina/.

Johnson, K. (2014): Hungary Is Helping Putin Keep His Chokehold on Europe's Energy. Foreign Policy. available at: http://foreignpolicy.com/2014/11/06/hungary-is-helping-putin-keep-his-chokehold-on-europes-energy/.

Karaffa, V. - Balabán, M. - Rašek, A. (2008): Vývoj bezpečnostní politiky a strategie ČR v období 1990-2009. Vojenské rozhledy, 18 (4): 5-22.

Khol, R. et al. (2004): Česká bezpečnostní politika 1993-2004. Zahraniční politika České republiky 1993-2004. Úspěchy, problémy, perspektivy. Praha: Ústav mezinárodních vztahu, 31-44.

Kmec, V. - Korba, M. - Ondrejcsák, R. (2005): Transformácia NATO a bezpečnostná a obranná politika SR. Bratislava: Centrum bezpečnostných štúdií.

Kořan, M. (2012): Dvě dekády české zahraniční politiky a bezvýchodnost internacionalistické hegemonie. Politologický časopis 2012 (3): 195-217.

Kořan, M. et al. (2014): Česká zahraniční politika v roce 2013. Analýza ÚMV. Praha: Ústav mezinárodních vztahů, 2014. 473. ISBN 978-80-87558-19-5.

Krčál, P. - Naxera, V. (2015): Vztah korupčního jednání a státního aparátu. Politologická revue 21 (2): 73-93.

Longhurst, K. - Zaborowski, M. (2007): The New Atlanticist. Poland's Foreign and Security Policy Priorities. London: The Royal Institute of International Affairs.

Machnikowski, R. M. (2015): NATO and the Ukraine - Russian Armed Conflict. In: Czulda, R., Madej, M. eds., Newcomers No More? Contemporary NATO and the Future of the Enlargement from the Perspective of "Post-Cold War" Members. Varšava: International Relations Research Institute, 231-245.

Mazalová, V. (2006): Strategické dokumenty ČR a jejich reflexe v oblasti finančních zdrojů pro potřeby ozbrojených sil. Obrana a strategie, 2006 (1): 61-70.

Nagy, L. - Kovács, T. (2006): Hungary 's Security and Defence Policy in the new geostrategic environment. TÉvXoৎ 2006 (35), available at: http://www.elesme.gr/elesmegr/periodika/t35/ t35_09.htm.

NATO-U.S. Military Presence in Poland. (2018): [on-line]. available at: https://pl.usembassy.gov/ nato_us/.

Naxera, V. (2017): Rusko, demokracie a postsovětský prostor - vybrané aspekty politického myšlení Alexandra Solženicyna. Politické vedy, 20 (3): 28-44.

Nowakowski, Z. - Protasowicki, I. (2008): Polska w euroatlantyckiej przestrzeni bezpieczeństwa. miejsce polski w NATO i Unii Europejskiej. In Bezpieczeństwo narodowe i zarządzanie kryzysowe w Polsce w XXI wieku - wyzwania i dylematy. Wyższa Szkola Informatyki, Zarządzania i Administracji, available at: http://www.dobrauczelnia.pl/upload/File/KONFERENCJE/BAZPIECZENSTWO/Nowakowski_Protasowicki.pdf. 
Orbánov minister zahládza rozruch okolo autonómie. (2014): In Pravda.sk. [on-line]. available at: http://spravy.pravda.sk/svet/clanok/317607-orban-nehovoril-o-uzemnej-autonomii-tvrdi-sef-diplomacie-madarska/.

Pástor, Z. (2004): Politické dejiny strednej Európy po roku 1945. Banská Bystrica: Univerzita Mateja Bela.

Pomorska, K. (2011): Are we there yet? From adaptation to Europeanisation of Polish foreign policy. Boston: Maastrich University, available at: http://euce.org/eusa/2011/papers/7j_pomorska.pdf.

Spilý, P. (2014): Regionálna obranná spolupráca krajín V4. Bezpečnostné fórum 2014, 1. volume. Banská Bystrica: Vydavatel'stvo Univerzity Mateja Bela - Belianum, s. 19-26.

Ušiak, J. - Ivančík, R. (2014): Economy and Defence in the NATO Member States. ECONOMIC ANNALS - XXI, 7-8 (2): 8-12.

Ušiak, J. (2012): Bezpečnostná politika Slovenskej republiky a vybrané bezpečnostné dokumenty. Banská Bystrica: Univerzita Mateja Bela

Waisová, Š. (2010): Change of value preferences of Czech Society and of foreign policy makers as one of prerequsites of transformation of Czech Foreign policy character. Sociální studia 7 (4): 145-157.

Waisová, Š. - Piknerová, L. (2012): Twenty Years After: Dissident Tradition in Czech Foreign Policy Matters. East European Politics and Societies 26 (1): 162-188. Doi: 10.1177/0888325411404553.

Jaroslav Ušiak works at the Department of Security Studies, Matej Bel University in Banská Bystrica/Slovak Republic. He focuses on the issues of sector security of the state, state sovereignty, devoting primary attention to the societal sector and the problem of identities. He also deals with the security theories and IR theories and focusing on regional security mainly in Central Europe. He is author or co-author of more than one hundreds scholar publications. Among the most recent we can mention books Poland and Slovakia: Bilateral Relations in a Multilateral Context (2004-2016) (with Joanna Dyduch, Igor Kosir and Sebastian Jakubowski), Bezpečnost' ako kategória [Security as a category] (with Jana Lasicová), Security Policy of the Slovak Republic - Development, Cornerstone and Implications, Security and Strategic Culture of the Visegrad Group Countries.

E-mail: jaroslav.usiak@umb.sk 